\title{
Historiography and non-Western pasts
}

This special issue of Postcolonial Studies brings together essays by six scholars of diverse interests and backgrounds - a historian-anthropologist of the Pacific, an anthropologist-historian of indigenous Australia, a social theorist, a philosopher of history, and two of the founding editors of this journal who are also historians of India. What they have in common is that the nature of their intellectual work involves them in writing the history of those who do not necessary live 'in' history, or to put it another way, that they write histories, of the modern, 'rational' type, of peoples who would often not recognize themselves or their pasts in these histories - but who, needless to say, have their own way(s) of relating, and relating to, their pasts. We wagered that it would prove interesting and productive to bring together, in a workshop, ${ }^{1}$ those who in the course of their writing had reflected upon this fact and made it an integral part of their intellectual practice. That is, to bring together those who in connection with their own various subject matters have asked questions such as: When you write a history or ethnography of those who treat gods, spirits and ancestors as historical actors and as living contemporaries, is it adequate to 'anthropologize' these and treat them merely as 'evidence' of their subjects' 'beliefs'? Is there any reason to accord modern historiography epistemic privilege, treating it as superior to so-called myth, epic, legend and the Dreaming? What is the epistemic status of these and other modes of thinking and representing the past? Are these and modern historiography simply 'incommensurable', or is it possible to write historiography and do ethnography in ways that are dialogic, such that our categories for understanding the past encounter rather than write over and subsume those of others?

The first two essays in this collection practise the writing of history whilst meditating on what it is that they are doing, and how it might be done differently. Greg Dening offers a phenomenology of the past - the past, not as books and 'Theory and Method' classes, but as 'a common, everyday phenomenon ....Everyperson's fine sense of the poetics of their history making'. This, he suggests, is how the Pacific or Polynesian peoples - the Sea Peoples of the Sea Islands, in his (and their) preferred description-conceived of their own historicity, which they re-presented and re-lived by telling stories, by dancing them and by ritual memorialization. He examines a map made by Tupaia, priest of 'Oro in modern Tahiti, for Captain Cook, of 147 islands in the Sea of Islands. This was a subject of Dening's early work, when, as a young scholar, more than half a century ago, he sought to show that the traditional legends of Pacific islanders, recounting how they (in the absence of any navigational technology) voyaged and settled their islands, were perfectly plausible; that Tupaia's map was not pure myth. Now, as an older and very distinguished historian of the Pacific, he returns to this map in a different

ISSN 1368-8790 print/ISSN 1466-1888 online/08/020139-6 (C) 2008 The Institute of Postcolonial Studies DOI: $10.1080 / 13688790802001642$ 
vein, suggesting that if historians and anthropologists, who live other people's pasts so vicariously, are capable of humility and respect, they can see the map for what it manifestly is, 'a stilled moment in the phenomenology of a 2000 year past', can see it as a metaphor - as is all history - that gives voice to the past and conjoins it to the present. The end result is a meditation, in luminous prose, on history not simply as something that happened, but as a mode of collective being and belonging.

Deborah Bird Rose is also concerned with exploring alternative ways of engaging the past, and, in doing so, with remaining open to thinking 'the historical' as - in Heidegger's words -'not only something from which one gets information, and about which there are books; ... [but] much more, what we ourselves are, that which we bear'. ${ }^{2}$ Rose is additionally concerned to develop an ecological understanding which recognizes the relational and intersubjective nature of the link between humans and what some humans have learned to regard as a disenchanted nature, an object to be known and manipulated. These two concerns come together through the stories that have been told to her by her aboriginal teachers in Australia's Northern Territory, stories that are accounts of the past directed toward the present, and stories which, in her retelling and reading of them, seek not only to break colonial frames of understanding, but in so doing also 'break the frames of western historiography'.

In these stories dingoes and trees figure not as part of a 'nature' that is separate from humans, but rather 'are uniquely connected to humans as Dreaming ancestors and contemporary kin'. The personhood of one of her aboriginal teachers and interlocutors, Daly Pilbara, is, she explains, 'situated in country and in time; it is situated in the ongoing generations of trees and people who hold in their lives and in their actions the power of the life that has been and is still coming'. Thus when the white-barked eucalyptus trees near a homestead in the Northern Territory are chainsawed, it is a double destruction - ecological vandalism that is also the destruction of Dreaming trees where a fish Dreaming known as Jajiki had transformed into trees. And if, Rose asks, 'the relationship between past and present lies in ongoing generational partnerships among living beings', how can the relationship continue - how can there be 'history'? As Daly Pulkara says in sorrow and anger, when confronted by the massacred trees, 'we'll run out of history, because Whitefellas fuck the Law up, and they're knocking all the power out of this country'. In Latour-esque style, Rose's essay mixes trees, chainsaws and dingoes, science and Dreaming, philosophy and stories, to make a powerful argument and plea for thinking the past in a way which is open to the Other and, in so being, also involves a different mode of engaging and inhabiting the Earth.

The next two essays are concerned with the uses and abuses of historywith what history-writing can and cannot do, and with its social effects. Dipesh Chakrabarty asks what role professional history can play in public life, at a time when history is increasingly used to ground identities and mobilized in claims for dignity, resources and social justice. In contemporary India, as Chakrabarty shows, there has been a proliferation of combative 
identity-histories, narratives which mobilize the past for current political purposes, but that show scant respect for the evidentiary and argumentative protocols of history-writing. Indeed, the passionate debates in Indian public life are characterized by the fact that there is an almost inversely proportional relation between appeals to the historical record on the one hand, and the importance accorded to history-as-discipline (and the influence exercised by its professional practitioners), on the other.

Chakrabarty's essay documents a period from the late nineteenth century, when there was - in Rabindranath Tagore's words - an 'enthusiasm for history', conceived of as a 'scientific' and 'modern' practice which had an important and beneficial public and pedagogic role to play, not least that of demonstrating the fundamental unity that underpinned all the religious, linguistic and caste diversity of India. However, as nationalist politics in the early decades of the twentieth century drew more and more classes into the nationalist movement, the past very quickly became a locus for what we would today call 'identity politics'. And as the past became a site where partisan passions were played out, the idea of historical knowledge 'as a universal, as some kind of a public good, was clearly in crisis'. That crisis has only deepened in contemporary India, as marginalized and oppressed groups, and sometimes dominant groups, have mobilized the past for contestatory histories marked by 'a rampant sense of perspectivalism', histories which are uninterested in 'seeking validation from the historian's history'. As Chakrabarty insists, this is itself an outcome of decolonization and democratization, as groups that have been excluded or marginalized in mainstream histories have sought to contest and rewrite history. Their political claims are often just, and the claim that there must be space for multiple narratives and perspectives in history-writing has ample justification, and indeed is presupposed by the essays in this volume. But there is a problem here, and it is not simply the pseudo-problem the bogey of relativism. Insofar as contestatory or subaltern histories seek to reshape a collective, general history, they presuppose a (regulative) ideal of a history that transcends, or is not merely the sum of, particular, perspectival, and sometimes conflicting histories. But, as Chakrabarty asks, 'do we know what this "collective general history" is when all ideas of "universal history" have been abandoned?' History-as-discipline, if it is to play any role and make any contribution to the historical debates that animate and frequently divide our public life, must presuppose and posit 'some form of shared and general if not universal history'; and yet it is precisely this sense of a shared and general history that is implicitly challenged, and undermined, by the history-as-contestation which is the outcome of, and is enabled by, democratization and decolonization. Is it at all possible to 'retrieve' a collective singular, which history is the history 'of', but to do so without calling into play those false and oppressive universals that still need to be unmasked? This is not a question to which there is any easy answer, but Chakrabarty's essay concludes on a utopian note, anticipating, in the light of a looming environmental crisis that affects us as a species, the emergence of the human species as the collective singular whose past history-writing may, one day, recount. 
An optimism of the will also characterizes Jörn Rüsen's essay, which similarly seeks humanity as the subject of a new humanism, a humanism-tobe, born out of the shadow of the Holocaust. With his colleagues at the Institute for Advanced Study in the Humanities in Essen, Rüsen has for some years been engaged in a project to found a 'new' humanism, one which takes into account the limitations of the European humanism that revealed its moral exhaustion at Auschwitz, if not earlier. Such a new humanism, he declares, will be founded in and on history, concerned as it is with the life of the species in all its variety. Yet history would seem to offer a challenge to any universalist humanism, for its variety is the source of immense cultural diversity; and because history is that 'slaughter bench' of which the Holocaust is, perhaps, the paradigmatic example. Rüsen asks, as others have done, 'Has the tradition of Western humanism not been murdered in Auschwitz?'; 'How can humanism ... come to terms with this experience of radical and universal dehumanization?' The Holocaust was a historical event and yet we certainly cannot treat the Holocaust historically, as we might other events, for to do so would be to miss its enormity, and the challenge it poses to the idea of history as a coherent narrative demonstrating and thus providing continuities between past, present and future. If a humanism for our times is to be grounded in, or even bear any meaningful relation to, history, it has to be a concept of history that has opened itself to 'catastrophic experiences of inhumanity'.

To be able to think and write history in the aftermath of the Holocaust, suggests Rüsen, we need to open it up to mourning and suffering. Suffering has been conspicuous by its absence, as a category, in the humanities and social sciences, even though it has been, very obviously, an important feature of the human life these sciences seek to understand and represent; and mourning has been relegated to the place of a private 'emotion' pertaining to private griefs. The optimism and triumphalism of the humanism(s) of old died, or should have done so, in Auschwitz; if a new humanism is to be even remotely thinkable, it must eschew such celebration and self-congratulation, and embrace mourning, suffering, and human vulnerability and fragility. As Rüsen phrases it, in a deliberately paradoxical and powerful formulation, 'By mourning the loss of humanity the Holocaust has brought about, and accepting and working this into our historical understanding of what it means to be human, a lost humanism is kept present and given a future perspective in its absence.'

Barry Hindess writes neither as a historian nor as an anthropologist, but as a social theorist aiming 'to unsettle conventional academic ways of thinking about the West's special place in history, and thus also about the not-sospecial places occupied by non-Western peoples'. This way of thinking is one in which history and time are so conceived that it becomes possible to think of those who are our contemporaries as nonetheless inhabiting a time-past, an earlier 'stage' or 'epoch' in human development. In a famous phrase, Johannes Fabian described this way of thinking as entailing a 'denial of coevalness'; ${ }^{3}$ Hindess arrestingly characterizes it as the view that, 'Scattered across the realm of the present...there lies an archipelago of deprived 
temporal gulags which serve as detention centres or rudimentary training camps for contemporaries who have been condemned to the more or less distant past.' Not stated as often in public as it was in the days when this served as one of the prime justifications for colonial rule, this presumption is nonetheless still alive and well, and ever-present in the practices of international financial and aid agencies, and wealthy states, and also in the practices of postcolonial elites engaged in 'modernization' and 'nationbuilding'.

Hindess is not concerned with refuting this view, for he rightly takes it for granted that this is intellectually untenable and ethically and politically repugnant - and often catastrophic in its effects. He is more concerned with tracing its sources, which he finds neither principally in anthropology (Fabian), nor in Orientalism (Said), nor in Romanticism (Chandler), but in an earlier moment. Drawing upon but complicating Constantin Fasolt's recent argument that historical consciousness develops in the course of the 'historian's revolt' against the Holy Roman Empire and Papacy, Hindess provides a fascinating genealogy of the 'temporalizing of difference', a genealogy that is part alternative and part supplementary to other genealogies that have been offered. His essay traces locating difference in temporality back to Classical times, while showing that by the sixteenth and seventeenth centuries a different and more inclusive form of it had developed, one which was then available to Orientalism and Romanticism - and which continues to undergird the 'good intentions' of modern Western cosmopolitanism.

Following the lead of Claude Lévi-Strauss, Seth argues that history-asdiscipline is not simply the representation of 'the past' - as if the past were simply lying available but mute, waiting for the historian to give it voice but is rather a code that constructs its object. If it is a code, what is it, he asks, that historiography encodes? Seth's answer is that it encodes the humanist or anthropological presumption that has been more generally codified in Western thought from the early modern period - the presumption that behind art, culture, documents, morality, law, custom, gods and monuments there always lurks Man, and that all these artifacts are products and traces of what Man in different periods and cultures has thought and done. This presumption is thematized and well summed up in Max Weber's formulation: 'The transcendental presupposition of every cultural science ... is that we are cultural beings, endowed with the capacity and the will to take a deliberate attitude towards the world and to lend it significance. ${ }^{4}$

Drawing upon Nietzsche, Heidegger, and their heirs, Seth's essay argues to the contrary that the characteristically modern sequence of cause and effect needs to be reversed: it is not because Man is the origin and source of meaning and values that he is the subject of anthropology and history, but rather ... it is this presupposition and its correlates, embedded in our culture and our thought, that serve to create and secure humanism and anthropology'. Historiography is one of the important sites in and through which such anthropological presumptions are secured. This constitutes a problem for the code of history whenever it is applied to a subject matter where the anthropological/humanist presumptions of this code are absent, and Seth 
concludes his essay by suggesting that when applied to non-Western pasts the code of history 'is neither the "right" way of recounting pasts, [and] nor does it illuminate the traditions of the peoples whose pasts these are'.

The essays in this issue are concerned with how people think historicity, and whether history-writing of the modern, professional type is always adequate to thinking the past - and, in particular, to thinking the pasts of those who do not always represent and relate to their historicity through the knowledge procedures and protocols of history-as-discipline. In doing this, they also, indirectly and in some cases directly, raise the question of what history is 'for' - what functions it performs, and what its uses and limits are. The first line of questioning is the necessary prelude to the second, for as long as we continue to conceive of modern history-writing as the right and true way of representing the past - and myth, epic, legend and the Dreaming as 'untrue', or as early and inferior anticipations of rational, evidence-based historiography - the question of what purposes history performs barely arises, for truth appears as its own justification and reward. It is only when we take seriously the challenge offered to modern history-writing by other ways of recounting and relating to the past, that we can also begin to go beyond the banalities that we too often offer up in answer to the question (posed, for example, by prospective students at university 'Open Days'), 'What good is history, and what is it for?'; banalities such as 'You don't know where you're going unless you know where you came from.' The vigorous public debates on the uses and abuses of history in Australia, India and elsewhere indicate that this is a question of pressing ethical and political, and not only epistemological, importance. We offer these essays as a contribution to these ongoing debates.

\section{Notes}

${ }^{1}$ This workshop/conference was held in Melbourne at La Trobe University in June 2007, and was funded by the South Asia Node of the Asia-Pacific Futures Research Network, and also by the La Trobe Institute for India and South Asia, both of which I headed at the time. The essays presented at this occasion were then reworked, though authors were encouraged, if they wished, to retain the conversational style of their presentations. Other participants included Henry Reynolds, Bain Attwood, Stephen Muecke, Debjani Ganguly, Tony Birch and Chris Healy. An edited book is planned that will bring all these contributions under one cover.

2 Martin Heidegger, 'Annotations', quoted in Jeffrey Barash, Martin Heidegger and the Problem of Historical Meaning, Dordrecht: Martinus Nijhoff, 1988, p 143.

${ }^{3}$ Johannes Fabian, Time and the Other: How Anthropology Makes its Object, New York: Columbia University Press, 1983.

${ }^{4}$ Max Weber, 'Objectivity in Social Science and Social Policy', in Edward Shils and Henry Finch (eds), The Methodology of the Social Sciences: Max Weber, New York: Free Press, 1949, p 81. 